\title{
The Monsanto decision: The edge or the wedge
}

\author{
Left out of almost all reporting on the Canadian Federal Court's recent ruling in Monsanto v. Schmeiser \\ were the implications of the decision on patenting plants—something that Canada has not permitted.
}

\author{
E. Richard Gold and Wendy A. Adams
}

$T^{2}$ he Federal Court of Canada's decision in Monsanto Company v. Percy Schmeiser (reported last month ${ }^{1}$ ) has potentially farreaching and disturbing implications. Intellectual property protection for biotechnological innovation has been granted with the tacit understanding that whereas corporations may acquire patents for genes and processes using genes-for example, genetic testing for breast cancer-the scope of protection does not extend to the plants and animals in which patented genes are inserted. The Federal Court's decision allows Monsanto to do indirectly what Canadian patent law has not allowed them to do directly: namely, to acquire patent protection over whole plants.

Monsanto, through genetic engineering, has produced a strain of canola resistant to Monsanto's herbicide marketed under the name Roundup. The purported advantage to herbicide-resistant "Roundup Ready" canola is that Roundup herbicide can be sprayed liberally after the crop has emerged, killing off all other plant life but leaving the canola untouched. Monsanto claims that this procedure offers significant cost savings over more traditional methods of cultivation.

In 1993, Monsanto was issued a Canadian patent for the genetically engineered gene and cells containing those genes. Monsanto does not sell its genetically modified seeds. Instead, it has developed licensing arrangements whereby farmers, in exchange for a licensing fee and other commitments, are permitted to use the seed for planting one crop only. Seeds resulting from this crop, however, cannot be used for replanting in subsequent years.

As the well-known adage would have it, build a better mousetrap and the world will beat a path to your door. Without patent protection, however, the deserving inventor would not necessarily receive a steady flow of traffic. The first customer to buy the better mousetrap would be free to duplicate the process in his own workshop. He would probably be able to turn around and offer the

E. Richard Gold and Wendy A. Adams are assistant professors on the faculty of law at the University of Western Ontario, London, ON, Canada N6A3K7 (ergold@uwo.ca). product at a lower cost, given that he would not have to recoup any investment in research and development. With patent protection, the inventor is given the exclusive right to build the better mousetrap. Customers may indeed sell the mousetraps they have purchased, but unless they receive permission from the inventor, they are not allowed to start up rival production facilities.

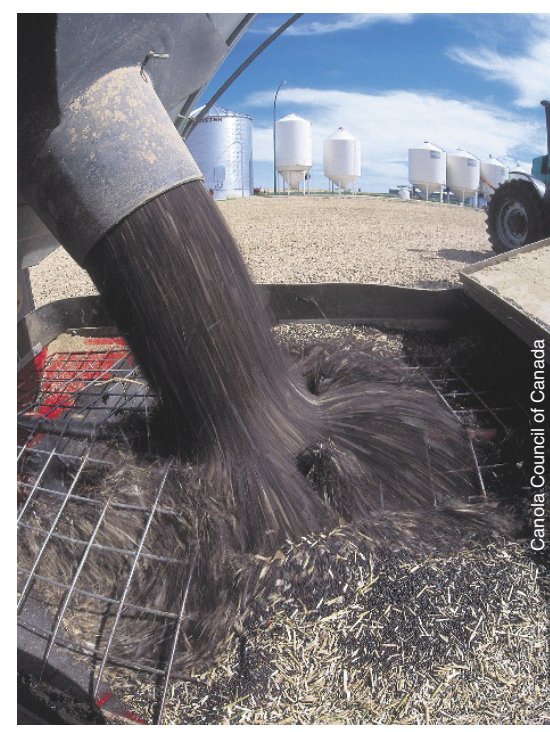

Canola seed being loaded for delivery to a farm east of Winnipeg, Manitoba.

In relation to inventions resulting from genetic modifications, it is important to note the difference between an inventor's exclusive right to the blueprint for a better mousetrap, and building a better mouse. The principal distinction between traditional patented technologies and the products of biotechnological innovation is the capacity for progeny. A mousetrap cannot replicate itself, but a canola plant can. Any plant containing Monsanto's genetic modification, regardless of whether generated through insertion directly into the DNA of canola cells or through natural means, is now subject to Monsanto's intellectual property rights. Had Monsanto attempted from the outset, however, to acquire patent protection for the genetically modified whole plant itself, instead of merely the modified gene and cells, Canadian patent office policy would not have permitted this.

The implications of this decision go far beyond agriculture. Although Canada has been liberal in granting patents over genes and cells whether of plant, animal, or human origin, the Canadian patent system is only now coming to grips with the issue of whether whole plants and animals are subject to patent law. The issue may soon reach the Supreme Court of Canada if leave to appeal is granted from the decision of the Federal Court of Appeal of August 2000, with respect the so-called Harvard oncomouse, which was genetically engineered to be susceptible to cancer.

The distinction between genes and cells on the one hand and whole plants, animals, and humans on the other has been the subject of fierce debate among biotechnology companies, environmental groups, academics, researchers, and government representatives. In fact, the Canadian Biotechnology Advisory Committee has recently held roundtable discussions across Canada with representatives from industry, nongovernmental agencies, and governments on the patenting of higher life forms. The committee is seeking input from stakeholders and members of the public in order to formulate recommendations to be delivered to the federal government this summer. The Monsanto decision preempts this debate, because it effectively grants a patent holder rights in not only a gene, but in the whole life form. Other legal tools were available to protect Monsanto's commercial interests without needing to push patent law in this direction.

Following the reasoning of the decision to its logical conclusion, we believe that we have reason to be concerned. Read literally, the decision means that by the simple act of reproduction, patients treated with germline gene therapy could be liable for patent infringement. The fact that germline gene therapy is very much fraught with ethical problems and echoes of eugenics at the moment suggests that this is unlikely to occur in practice any time soon; however, the possibilities signal that the decision in the Monsanto case leaves much to be desired.

1. Fox, J.L. Nat. Biotechnol. 19, 396-397 (2001) 